\title{
МЕХАНІЗМИ РОЗВИТКУ АДРЕНАЛІНОВОГО ПОШКОДЖЕННЯ МІОКАРДА У ЩУРІВ 3 РІЗНОЮ РУХОВОЮ АКТИВНІСТЮ
}

Вступ. Однією з причин розвитку серцево-судинної патології є стреси, при яких виділяється надмірна кількість катехоламінів, що спричинюють розвиток патології.

Мета дослідження - оцінити розвиток оксидативного стресу в гомогенаті серця щурів-самців 3 різною руховою активністю при адреналіновому пошкодженні міокарда.

Методи дослідження. Досліди виконано на безпородних щурах масою 180-220 г. Відбір тварин за руховою активністю здійснювали методом "відкрите поле". Забій тварин проводили через 1 і 24 год після ін'єкції адреналіну, визначали вміст дієнових кон'югатів (ДК), ТБК-активних продуктів (ТБК-ап), окисномодифрікованих протеїнів (ОМП), супероксиддисмутазну (СОД) і каталазну (Кат) активність. Проводили морфологічне дослідження міокарда у препаратах, забарвлених за Гейденгайном.

Результати й обговорення. У контролі у високоактивних самців, порівняно з низькоактивними, переважали продукти пероксидного окиснення ліпідів (ДК, ТБК-ап) і ОМП, також вищою була СОД і Кат активність. На початку розвитку адреналінового пошкодження міокарда в усіх тварин зріс вміст ДК, ТБКап, ОМП, причому він залишався більшим у високоактивних щурів. Зростала активність антиоксидантів. Причому різниці в СОД активності між двома групами тварин не спостерігали, а Кат активність була вищою у низькоактивних самців. Кількість некрозів виявилася більшою у щурів з високою руховою активністю. Через 24 год після введення адреналіну відмічено подальше зростання вмісту ДК, ТБК-ап, ОМП порівняно з контролем і попереднім терміном дослідження. Також відзначено зменшення антиоксидантної активності, що не відрізнялося від показників контрольних тварин, але тільки у самців з низькою руховою активністю. У щурів з низькою руховою активністю активність антиоксидантів перевищувала значення контролю, а також була більшою, ніж через годину після введення адреналіну, та вищою, ніж у тварин 3 високою руховою активністю. Зміни показників, що вказували на розвиток пошкодження, були достовірно більшими у тварин з високою руховою активністю.

Висновки. Розвиток адреналінового пошкодження серця залежить від рухової активності тварин. Більш виражену різницю відмічали протягом усього експерименту. Вища активність антиоксидантів запобігає значному пошкодженню міокарда.

КЛЮЧОВІ СЛОВА: пероксидне окиснення ліпідів; антиоксидантна система; серце; адреналін; рухова активність.

ВСТУП. Провідне місце при виникненні патології серцево-судинної системи займає проблема некоронарогенного ураження міокарда. Однією з причин появи некрозів є вплив великих доз катехоламінів. Їх збільшення можна спостерігати при стресі надмірної сили чи високої частоти. При цьому посилюється робота серця, а в клітинах запускається каскад реакцій, пов'язаних із розвитком гіпоксії $[1,2]$. У результаті зменшується напруження оксигену в органах i тканинах, виникає десріцит аденозинтрисросорату, іони кальцію накопичуються в клітинах та позаклітинному просторі, що викликає пошко-

(с) О. В. Денефіль, Т. Я. Ярошенко, М. І. Мединський, У. В. Котюк, 2021. дження, підвищується активність фоссрорилаз, відбувається роз'єднання процесів окиснення і фоссрорилювання, при зростанні енергодесріциту та накопиченні іонів кальцію настає загибель клітин. При гіпоксії, впливі катехоламінів в організмі посилюються процеси пероксидного окиснення ліпідів і протеїнів, що залежить від рівня метаболізму, ступеня активації системи антиоксидантного захисту, зокрема антиоксидантних ензимів (супероксиддисмутаза, каталаза) та природних антиоксидантів (токоферол, аскорбінова кислота), які сповільнюють окисні процеси [2-4].

У виникненні, перебігу і наслідках захворювань важливе значення належить реактивності організму [5], що забезпечує різну резистентність 
до стресів, холоду, крововтрат, гіпоксії [6], дії різних лікарських засобів. У популяціях є люди 3 різною руховою активністю. В експерименті для визначення особин серед дрібних лабораторних тварин з різною руховою активністю використовують тест "відкрите поле" [7]. Тварини у пристрої "відкрите поле" білого кольору перебувають під впливом стресу, що відображається на їх поведінці [8]. Виявлені особливості поведінки в цьому тесті дають змогу оцінити особливості стійких і нестійких до емоційного стресу тварин, вивести коефіцієнт індивідуальної прогностичної стійкості до стресу [9].

Мета дослідження - оцінити розвиток оксидативного стресу в гомогенаті серця щурів-самців з різною руховою активністю при адреналіновому пошкодженні міокарда.

МЕТОДИ ДОСЛІДЖЕННЯ. ДосЛіди виконано на безпородних щурах масою 180-220 г. Тварин розділено на 2 групи: контроль (К), адреналінове пошкодження міокарда (АПМ). Рухову активність визначали за методикою "біле відкрите поле" (кругла арена діаметром 160 см). За однонаправленою кількістю пересічених квадратів і вертикальних стійок відбирали щурів з високою і низькою руховою активністю [10].

Щурів утримували на стандартному харчовому раціоні віварію протягом усього періоду та з вільним доступом до води для пиття. Для моделювання АПМ тваринам внутрішньочеревно вводили 0,18 \% розчин адреналіну гідротартрату з розрахунку 0,5 мг/кг маси. Дослідження виконували через 1 і 24 год після ін'єкції препарату, що відповідало початку розвитку міокардіодистрофії та розгорнутій картині патологічного процесу. Усім тваринам проводили гістологічне дослідження серця на рівні обох шлуночків, виявлено збільшення клітин у стані апоптозу порівняно з контрольною групою та некротизовані кардіоміоцити в мікропрепаратах, зафарбованих за Гейденгайном. Апоптоз і некроз переважали у тварин з високою руховою активністю у два терміни дослідження, значно збільшувалися через 24 год порівняно 31 год, що знову ж таки було більш виражено серед високорухливих щурів.

Усі експерименти проводили в першій половині дня в спеціально відведеному приміщенні при температурі $18-22^{\circ} \mathrm{C}$, відносній вологості 40-60 \% і освітленості 250 лк. Досліди виконано з дотриманням норм Європейської конвенції про захист хребетних тварин, що використовуються для дослідних та інших наукових цілей (Страсбург, 18.03.1986 р.), ухвали Першого національного конгресу з біоетики (Київ, 2001) і наказу МОЗ України від 23.09.2009 р. № 690.
Евтаназію щурів проводили шляхом тотального кровопускання із серця після попереднього використання тіопентал-натрієвого наркозу (60 мг к $^{-1}$ маси тіла тварини внутрішньочеревно). Із застосуванням загальноприйнятих методику гомогенаті серця визначали стан пероксидного окиснення ліпідів (ПОЛ) за вмістом дієнових кон'югатів (ДК), ТБК-активних продуктів (ТБК-ап), окисну модисрікацію протеїнів $\left(\mathrm{OM}_{370} \mathrm{i} \mathrm{OMП}_{430}\right)$, активність антиоксидантної системи, зокрема супероксиддисмутазну (СОД) активність і каталазну (Кат) активність [11-14].

Статистичну обробку циоррових даних виконано за допомогою програмного забезпечення Excel ("Microsoft", CШA) i STATISTICA 6.0 ("Statsoft", США). Достовірність різниці значень між незалежними кількісними величинами визначали при нормальному розподілі за критерієм Стьюдента, в інших випадках - непараметричними методами. Зміни вважали достовірними при $\mathrm{p} \leq 0,05$. Відмінності між величинами вважали достовірними за вірогідності альтернативної гіпотези не менше ніж 0,95 [15].

РЕЗУЛЬТАТИ Й ОБГОВОРЕННЯ. ПРОТЯГОМ перших 15 хв від початку експерименту відмічено смертність щурів: серед самців 3 високою руховою активністю вона становила $20 \%, 3$ низькою $-10 \%$.

У контрольних тварин з високою руховою активністю, порівняно з низькою, вміст продуктів ПОЛ був більшим, зокрема ДК - на 14,3 \%, а ТБК-ап - на 19,6 \% (табл. 1). Відповідно, вищими були показники ОМП 34,4 \% (табл. 2). Супероксиддисмутазна і каталазна активність також переважала у щурів 3 високою руховою активністю, відповідно, на 75 та 63,6 \% (табл. 3). Отримані дані вказують на те, що при високій руховій активності оксидативні процеси перебігають на вищому рівні. Статистично достовірної різниці між часткою апоптично змінених клітин не виявлено.

Адреналін викликав такі зміни результатів. Через 1 год відмічено достовірне збільшення практично всіх досліджуваних показників у самців як з високою, так і з низькою руховою активністю. Так, концентрація ДК зросла у самців 3 високою руховою активністю на 38,5 \%, з низькою - на 39,6 \%, і була вищою в перших на 13,4 \%. Вміст ТБК-ап збільшився у самців 3 високою руховою активністю на $64,2 \%, 3$ низькою на $72,3 \%$, і був вищим у перших на $48,2 \%$. Значення ОМП кою руховою активністю на $50 \%$, з низькою - на $61,9 \%$, і були більшими в перших на $41,2 \%$. Показники ОМП 430 зросли у самців з високою руховою активністю на 46,5 \%, 3 низькою - на 
Таблиця 1 - Зміни вмісту продуктів пероксидного окиснення ліпідів у гомогенаті серця щурів при адреналіновому пошкодженні міокарда (M $\pm m)$

\begin{tabular}{|c|c|c|c|c|c|c|}
\hline \multirow{4}{*}{ Показник } & \multicolumn{6}{|c|}{ Група } \\
\hline & \multirow{2}{*}{\multicolumn{2}{|c|}{ контроль }} & \multicolumn{4}{|c|}{ АПМ } \\
\hline & & & \multicolumn{2}{|c|}{1 год } & \multicolumn{2}{|c|}{24 год } \\
\hline & $\begin{array}{c}\text { високоактивн } \\
(n=10)\end{array}$ & $\begin{array}{c}\text { низькоактивні } \\
(n=10)\end{array}$ & $\begin{array}{c}\text { високоактивні } \\
(\mathrm{n}=8)\end{array}$ & $\begin{array}{c}\text { низькоактивні } \\
(n=9)\end{array}$ & $\begin{array}{c}\text { високоактивні } \\
(\mathrm{n}=8)\end{array}$ & $\begin{array}{c}\text { низькоактивні } \\
(\mathrm{n}=9)\end{array}$ \\
\hline ДК, ум. од./г & $1,04 \pm 0,03$ & $0,91 \pm 0,02^{\star \star}$ & $1,44 \pm 0,04^{*}$ & $1,27 \pm 0,04^{\star, \star *}$ & $2,39 \pm 0,06^{\star, \star \star \star}$ & $1,82 \pm 0,05^{\star, \star \star, \star \star \star \star}$ \\
\hline $\begin{array}{l}\text { ТБК-активні } \\
\text { продукти, } \\
\text { мкмоль/кг }\end{array}$ & $1,34 \pm 0,05$ & $1,12 \pm 0,05$ ** & $2,86 \pm 0,08^{*}$ & $1,93 \pm 0,09^{\star, \star *}$ & $4,25 \pm 0,08^{\star, \star \star \star}$ & $3,61 \pm 0,07^{\star, \star \star, \star \star \star}$ \\
\hline
\end{tabular}

Примітка. Тут і в таблицях 2, 3: * - різниця достовірна порівняно 3 контролем; *夫 - різниця достовірна порівняно 3 тваринами з високою руховою активністю; ** - різниця достовірна порівняно з 1 год розвитку АПМ.

Таблиця 2 - Зміни вмісту окисномодиорікованих протеїнів у гомогенаті серця щурів при адреналіновому пошкодженні міокарда (M $\pm m)$

\begin{tabular}{|c|c|c|c|c|c|c|}
\hline \multirow{4}{*}{ Показник } & \multicolumn{6}{|c|}{ Група } \\
\hline & \multirow{2}{*}{\multicolumn{2}{|c|}{ контроль }} & \multicolumn{4}{|c|}{ AПM } \\
\hline & & & \multicolumn{2}{|c|}{1 год } & \multicolumn{2}{|c|}{24 год } \\
\hline & $\begin{array}{c}\text { високоактивні } \\
(n=10)\end{array}$ & $\begin{array}{c}\text { низькоактивні } \\
(n=10)\end{array}$ & $\begin{array}{c}\text { високоактивні } \\
(n=8)\end{array}$ & $\begin{array}{c}\text { низькоактивні } \\
(\mathrm{n}=9)\end{array}$ & $\begin{array}{l}\text { високоактивні } \\
(n=8)\end{array}$ & $\begin{array}{c}\text { низькоактивні } \\
(\mathrm{n}=9)\end{array}$ \\
\hline $\begin{array}{l}\text { ОМП }_{370,} \\
\text { ммоль/г } \\
\text { протеїну }\end{array}$ & $0,32 \pm 0,02$ & $0,21 \pm 0,03$ ** & $0,48 \pm 0,03^{*}$ & $0,34 \pm 0,03^{\star, \star \star}$ & $0,58 \pm 0,02^{\star, \star \star \star}$ & $0,41 \pm 0,02^{\star, \star \star, \star \star \star \star}$ \\
\hline $\begin{array}{l}\text { ОМП }_{430} \\
\text { ммоль/г } \\
\text { протеїну }\end{array}$ & $0,43 \pm 0,02$ & $0,32 \pm 0,03$ ** & $0,63 \pm 0,05^{*}$ & $0,46 \pm 0,04^{\star, \star \star}$ & $0,81 \pm 0,03^{\star, \star \star \star}$ & $0,61 \pm 0,02^{\star, \star \star, \star \star \star}$ \\
\hline
\end{tabular}

Таблиця 3 - Зміни активності антиоксидантів у гомогенаті серця щурів

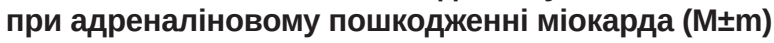

\begin{tabular}{|c|c|c|c|c|c|c|}
\hline \multirow{4}{*}{ Показник } & \multicolumn{6}{|c|}{ Група } \\
\hline & \multirow{2}{*}{\multicolumn{2}{|c|}{ контроль }} & \multicolumn{4}{|c|}{ AПM } \\
\hline & & & \multicolumn{2}{|c|}{1 год } & \multicolumn{2}{|c|}{24 год } \\
\hline & $\begin{array}{c}\text { високоактивні } \\
(\mathrm{n}=10)\end{array}$ & $\begin{array}{c}\text { низькоактивні } \\
(\mathrm{n}=10)\end{array}$ & $\begin{array}{c}\text { високоактивні } \\
(\mathrm{n}=8)\end{array}$ & $\begin{array}{c}\text { низькоактивні } \\
(\mathrm{n}=9)\end{array}$ & $\begin{array}{c}\text { високоактивні } \\
(n=8)\end{array}$ & $\begin{array}{c}\text { низькоактивні } \\
(n=9)\end{array}$ \\
\hline \begin{tabular}{|l} 
Супероксид- \\
дисмутазна \\
активність, \\
ум. од./мг
\end{tabular} & $0,21 \pm 0,02$ & $0,12 \pm 0,02^{\star \star}$ & $0,36 \pm 0,04^{*}$ & $0,37 \pm 0,03^{*}$ & $0,23 \pm 0,02^{\star \star \star}$ & $0,47 \pm 0,02^{\star, \star \star, \star \star \star \star}$ \\
\hline $\begin{array}{l}\text { Каталазна } \\
\text { активність, } \\
\text { мкат/кг }\end{array}$ & $0,18 \pm 0,01$ & $0,11 \pm 0,02^{\star \star}$ & $0,27 \pm 0,02^{*}$ & $0,36 \pm 0,02^{\star, \star \star}$ & $0,15 \pm 0,03^{\star \star \star}$ & $0,48 \pm 0,03^{\star, \star \star, \star \star \star \star}$ \\
\hline
\end{tabular}

43,8 \%, і були вищими в перших на 37 \%. Супероксиддисмутазна активність підвищилася у самців з високою руховою активністю на 71,4 \%, з низькою - в 3 рази, і в цей час зникала достовірна різниця між групами тварин з різною руховою активністю. Каталазна активність зросла у самців з високою руховою активністю на 50 \%, 3 низькою - в 3,3 раза, і переважала у других на 33,3 \%. Кількість клітин, які зазнали апоптозу і некрозу, була більшою в серці щурів з високою руховою активністю. Отримані дані вказують на те, що більша потужність антиоксидантної системи забезпечує знешкодження вільних радикалів. На початку розвитку АПМ, поряд із наростанням процесів руйнування клітинних мембран, відмічено підвищення активності антиоксидантів, що було більш виражено у тварин з низькою руховою активністю і забезпечувало менше пошкодження в них кардіоміоцитів.

Через 24 год АПМ, порівняно з контролем, концентрація ДК зросла у самців з високою руховою активністю у 2,3 раза, 3 низькою - на 90,1 \%, і була вищою в перших на 31,3 \%. Вміст ТБК-ап збільшився у самців з високою руховою активністю у 3,2 раза, з низькою - у 3,2 раза, і був вищим у перших на 17,7 \%. Значення ОМП підвищилися у самців з високою руховою активністю на 81,3 \%, з низькою - на 95,2 \%. Показники ОМП активністю на 88,4 \%, 3 низькою - на 90,6\%. 
Значення ОМП переважали у самців з високою руховою активністю, відповідно, на 41,5 і 32,8\%. Супероксиддисмутазна активність у самців 3 високою руховою активністю в цей термін дослідження не відрізнялася від контрольних значень, а з низькою вона зросла в 3,9 раза, і була більшою, порівняно з першими, у 2 рази. Каталазна активність у самців з високою руховою активністю не відрізнялася від контрольних значень, а 3 низькою вона зросла в 4,4 раза, і була більшою, порівняно з першими, у 3,2 раза. Кількість клітин, які зазнали апоптозу і некрозу, була більшою в серці щурів з високою руховою активністю. Отримані дані вказують на те, що більша потужність антиоксидантної системи забезпечує захисний ефект.

При порівнянні досліджуваних показників через 1 i 24 год після введення адреналіну відмічено поглиблення розвитку патологічного процесу, що було більш виражено у самців 3 високою руховою активністю. Так, вміст ДК через 24 год був вищим у самців з високою руховою активністю на $66 \%$, з низькою - на 43,3\%. Концентрація ТБК-ап була більшою у самців з високою руховою активністю на 48,6 \%, 3 низькою - на $87 \%$. Значення ОМП 3 високою руховою активністю на 20,8 \%, 3 низькою - на 20,6 \%. Показники ОМП 3 високою руховою активністю були більшими на 28,6 \%, з низькою - на 32,6 \%. Супероксиддисмутазна активність у самців з високою руховою активністю була меншою на 56 \%, з низькою - більшою на $27 \%$. Каталазна активність у самців з високою руховою активністю була меншою на 80 \%, з низькою - більшою на 33,3 \%. Отримані дані вказують на те, що антиоксиданти забезпечують менше пошкодження кардіоміоцитів при розвитку АПМ.

Одержані дані щодо змін біохімічних показників узгоджуються 3 морфрологічними змінами, які свідчать про більше пошкодження кардіоміоцитів самців з високою руховою активністю.

ВИСНОВКИ. Розвиток адреналінового пошкодження серця залежить від рухової активності тварини. Більш виражену різницю відмічали протягом усього експерименту. Вища активність антиоксидантів запобігає значному пошкодженню міокарда.

\section{СПИСОК ЛІТЕРАТУРИ}

1. Corcoran A. Hypoxia-inducible factor signaling mechanisms in the central nervous system / A. Corcoran, J. J. O'Connor // Acta Physiol. (Oxf). - 2013. - 208, No. 4. - P. 298-310.

2. Механизмы фрормирования острой экзогенной гипоксии и возможности ее фрармакологической коррекции антигипоксантами / Д. В. Сосин, О. Е. Шалаева, А. В. Евсеев, П. Д. Шабанов // Обзоры по клинич. фрармакологии и лекар. терапии. - 2015. - 13, № 1. C. 1-24.

3. Antioxidant and cytoprotective responses to redox stress / J. Mathers, J. A. Fraser, M. McMahon [et al.] // Biochem. Soc. Symp. - 2004. - No. 71. - P. 157-176.

4. Colombo M. L. An update on vitamin E, tocopherol and tocotrienol-perspectives / M. L. Colombo // Molecules. - 2010. - 15, No. 4. - P.2103-2113.

5. A possible role for systemic hypoxia in the reactive component of pulmonary hypertension in heart failure / B. J. Taylor., C. R. Mojica, T. P. Olson [et al.] // Journal of Cardiac Failure. - 2013. - 19, Issue 1. - P. 50-59.

6. Устойчивость к гипоксии у людей пожилого возраста с гипертонической болезнью: влияние Кардиоаргинина / О. В. Коркушко, Е. Д. Осьмак, Д. Д. Осьмак, Г. В. Дужак // Кровообіг та гемостаз. - 2015. № 1-2. - С. 31-37.

7. Выбор показателей поведенческих тестов для оценки типологических особенностей поведения крыс / А. В. Мельников, М. А. Куликов, М. Р. Новикова, Е. В. Шарова // Журн. высшей нервной деятельности им. И. П. Павлова. - 2004. - 54, № 5. - С. 712-717.

8. Буреш Я. Методики и основные эксперименты по изучению мозга и поведения / Я. Буреш ; пер. с англ. - М. : Высшая школа, 1991. - 399 с.

9. Влияние карбахолина и глицилпролина (GLYPRO) на секреторную фрункцию желудка в зависимости от реактивности ЦНС у крыс / Т. А. Томова, Т. А. Замощина, Е. Ю. Просекина, М. В. Светлик // Эксперим. и клинич. фрармакология. - 2015. - 78, № 3. - С. 13-16.

10. Гелиева Е. А. Динамика поведения лабораторных крыс в нормальных (контрольных) условиях в тесте "открытое поле" / Е. А. Гелиева, С. А. Дерюга, Г. А. Фролова // Вісн. студ. наук. тов-ва ДонНУ імені Василя Стуса. - 2013. - 1, вип. 5. - С. 269-274.

11. Хышиктуев Б. С. Методы определения продуктов перекисного окисления липидов в конденсате выдыхаемого воздуха и их клиническое значение / Б. С. Хышиктуев, Н. А. Хышиктуева, В. Н. Иванов // Клинич. лаб. диагностика. - 1996. - № 3. - С. 13-15.

12. Мещишен І. Ф. Метод визначення окислювальної модифікації білків плазми крові / І. Ф. Мещишен // Буковин. мед. вісн. - 1998. - 2, № 1. -С. 156-158.

13. Чевари С. Роль супероксиддисмутазы в окислительных процессах клетки и метод определения ее 
в биологических материалах / С. Чевари, И. Чаба, й. Секей // Лаб. дело. - 1985. - № 11. - С. 678-681.

14. Метод определения активности каталазы / М. А. Королюк, Л. И. Иванова, И. Г. Майорова, В. Е. Токарев // Лаб. дело. - 1988. - № 1. - С. 16-19.

\section{REFERENCES}

1. Corcoran, A. \& O'Connor, J.J. (2013). Hypoxiainducible factor signaling mechanisms in the central nervous system. Acta Physiol. (Oxf), 208 (4), 298-310.

2. Sosin, D.V., Shalaeva, O.E., Evseev, A.V., \& Shabanov, P.D. (2015). Mechanisms of the formation of acute exogenous hypoxia and the possibility of its pharmacological correction with antihypoxants. Reviews on Clinical Pharmacology and Drug Therapy, 13 (1), 1-24 [in Russian].

3. Mathers, J., Fraser, J.A., McMahon, M., Saunders, R.D., Hayes, J.D. \& McLellan, L.I. (2004). Antioxidant and cytoprotective responses to redox stress. Biochem. Soc. Symp., 71, 157-176.

4. Colombo, M.L. (2010). An update on vitamin E, tocopherol and tocotrienol -perspectives. Molecules, 15 (4), 2103-2113.

5. Taylor, B.J., Mojica, C.R., Olson, T.P., Woods, P.R., Frantz, R.P. \& Johnson, B.D, (2013). A possible role for systemic hypoxia in the reactive component of pulmonary hypertension in heart failure. Journal of Cardiac Failure, 19 (1), 50-59.

6. Korkushko, O.V., Os'mak, E.D., Oc'mak, D.D., \& Duzhak, G.V. (2015). Resistance to hypoxia in elderly people with essential hypertension: the effect of Cardioarginin. Blood Circulation and Hemostasis, 1-2, 31-37 [in Russian].

7. Melnikov, A.V., Kulikov, M.A., Novikova, M.R. \& Sharova E.V. (2004). The choice of indicators of behavioral tests to assess the typological characteristics of the behavior of rats. Journal of Higher Nervous Activity named after I. P. Pavlov, 54 (5), 712-717 [in Russian].
15. Лапач С. Н. Статистические методы в медико-биологических исследованиях с использованием Excel / С. Н. Лапач, А. В. Чубенко, П. Н. Бабич. - К. : Морион, 2000. - 320 с.
8. Buresh, J. (1991). Methods and basic experiments in the study of the brain and behavior: trans. from English. Moscow: Vysshaya shkola [in Russian].

9. Tomova, T.A., Zamoshchina, T.A., Prosekina, E.Yu., \& Svetlik, M.V. (2015). Influence of carbacholine and glycylproline (GLY-PRO) on gastric secretory function depending on the reactivity of the central nervous system in rats. Experimental and Clinical Pharmacology, 78 (3), 13-1 [in Russian].

10. Gelieva, E.A., Deryuga, S.A. \& Frolova, G.A. (2013). Dynamics of behavior of laboratory rats under normal (control) conditions in the "open field" test. Bulletin of the Vasyl Stus Student Scientific Society of DonNU, 5 (1), 269-274 [in Russian].

11. Khyshiktyev, B.S., Khyshiktyeva, N.A. \& Ivanov V.N. (1996). Methods for determination of lipid peroxidation products in exhaled air condensate and their clinical significance. Clinical Laboratory Diagnostic, 3, 13-15 [in Russian].

12. Meshchishen, I.F. (1998). Method for determination of oxidative modification of blood plasma proteins. Bukovynian Medical Bulletin, 2 (1), 156-158 [in Ukrainian].

13. Chevari, S., Chaba, I. \& Sekei, I. (1985). The role of superoxide dismutase in the oxidative processes of the cell and the method for its determination in biological materials. Laboratory Work, 11, 678-681 [in Russian].

14. Korolyuk, M.A., Ivaniva, L.I., Majorova, I.G. \& Tokarev, V.E. (1988). Metod for determination of katalaze activity. Laboratory Work, 1, 16-19 [in Russian].

15. Lapach, S.N., Chubenko, A.V. \& Babich, P.N. (2000). Statistical methods in biomedical research using Excel. Kyiv: Morion [in Russian]. 


\section{MECHANISMS OF ADRENAL MYOCARDIAL DAMAGE DEVELOPMENT IN RATS WITH DIFFERENT MOTOR ACTIVITY}

\section{Summary}

Introduction. One of the reasons for the development of cardiovascular pathology is stress, which releases excessive amounts of catecholamines, causing the development of pathology.

The aim of the study - to evaluate the development of oxidative stress in the heart homogenate of male rats with different motor activity in adrenaline myocardial damage (AMD).

Research Methods. The experiments were performed on purebred rats weighing 180-220 grams. Selection of animals for motor activity was carried out by the method of "open field". Experiment on animals was performed in control, 1 and 24 hours after injection of adrenaline, which determined diene conjugates (DC), TBA-active products (TBA-ap), oxidatively modified proteins (OMP), superoxide dismutase (SOD) and catalase activity (Cat). Morphological examination of the myocardium in Heidenhain-stained drugs was conducted.

Results and Discussion. In the control of highly active males, compared with low-activity, dominated by products of lipid peroxidation (DC, TBA-ap) and OMP, as well as higher superoxide dismutase and catalase activity. At the beginning of the development of AMD in all animals increased the content of DC, TBA-ap, OMP, and they remained higher in highly active rats. The activity of antioxidants increased. Moreover, the difference in SOD between the two groups of animals was not detected, and Cat was higher in low-activity rats. The number of necrosis was higher in animals with high motor activity. In 24 hours of AMD further increase of DC, TBA-ap, OMP, in comparison with control and the previous term of research was noted. There was also a decrease in antioxidant activity, which did not differ from those of control animals, but only in males with low motor activity. In animals with low motor activity, the activity of antioxidants exceeded the control value, and it was more than an hour after the injection of adrenaline. Changes in the indexes indicating the development of damage were significantly greater in animals with high motor activity.

Conclusion. The development of adrenaline damage to the heart depends on the motor activity of the animal. A more pronounced difference was observed in the experiment. Greater antioxidant activity prevents significant myocardial damage.

KEY WORDS: lipid peroxidation; antioxidant system; heart; adrenaline; motor activity.

Отримано 10.11.21

Адреса для листування: О. В. Денефіль, Тернопільський національний медичний університет імені І. Я. Горбачевського МОз України майдан Волі, 1, Тернопіль, 46001, Україна, e-mail: denefil@tdmu.edu.ua. 